\title{
INTERNATIONAL MARRIAGES IN JAPAN: MARITAL SATISFACTION IN COUPLES OF WESTERN WOMEN AND JAPANESE MEN
}

\section{Introduction}

While international marriages (kokusai kekekon) remain relatively rare in Japan, they have already eroded the notion of Japan as a mono-ethnic and mono-cultural society, and will continue to do so in the future.

Trends in international marriage in Japan

Figure 1 shows the trends in marriages between Japanese nationals and foreigners since 1965, when the data was first compiled. In the early 1970s, such unions represented only around $0.5 \%$ of all marriages registered in Japan but increased rapidly during the Japanese "bubble" economy of the 1980s, coinciding with the influx of immigration from other Asian countries. The trend continued even after Japan entered the period of economic stagnation in the early 1990 s, peaking at $6.1 \%$ in 2006 . In the following years, the proportion of international marriages has dropped dramatically, falling by almost half in 2013-2016. ${ }^{1}$ This sudden decline in international marriages has been associated primarily with more rigid immigration policies: the tightening of the requirements for obtaining "entertainment visas" in 2006 (which dramatically reduced the number of foreign - in particular Filipino - women entering the country to work as singers or dancers) and strengthened efforts to crack down on fake marriages involving in particular Chinese, Korean and Filipino women. ${ }^{2}$ Despite this decline, the proportion of international marriages $(3.4 \%)$ is still higher than the proportion of foreigners residing in Japan $(1.6 \%) .^{3}$ In absolute terms, 21,180 out of all wed couples were international marriages

1 Ministry of Health Labor and Welfare, Vital Statistics of Japan, 2016.

2 S. Takeshita, Intermarriage and Japanese Identity [in:] Creating social cohesion in an interdependent world: experiences of Australia and Japan, eds. E. Healy, D. Arunachalam, T. Mizukami, Palgrave Macmillan, New York 2016, pp. 176-177.

3 Own calculation based on: Ministry of Internal Affairs and Communications, Population Estimates, 2017. 


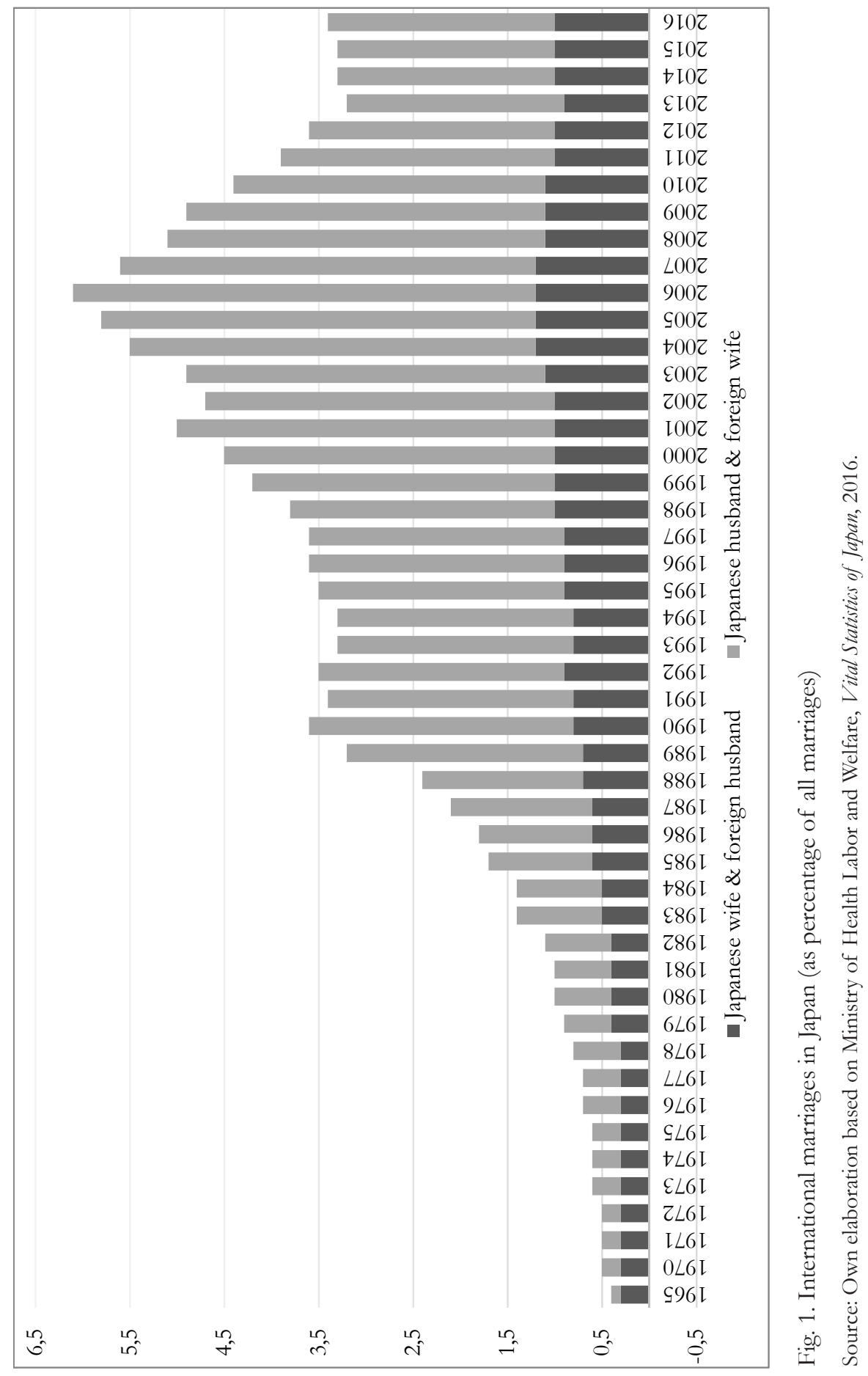


in 2016 compared to 4,156 in $1965 .{ }^{4}$ One thing to bear in mind is that these figures may exclude the couples that married abroad and did not return to Japan.

Looking at the gender patterns, the majority of international marriages in the post-war period brought together a Japanese wife and a foreign husband. The proportion equalised in mid-1970s and shifted thereafter. As of the late $1980 \mathrm{~s}, 70 \%$ to $80 \%$ of international unions have between a Japanese husband and a foreign wife.

Nationality of foreign spouses

As seen in table 1, the vast majority of foreign spouses are the nationals of neighbouring Asian countries, in particular China (31\%), South Korea (18\%) and the Philippines $(15 \%)$. This is not surprising, given that these are also the three most numerous groups of Japan's foreign residents. In fact, these three nationalities alone account for almost two-third of both international spouses in Japan and foreigners residing in Japan. As for the Koreans, the majority are so-called zainichi Koreans, i.e. "special permanent residents" of Japan who or whose ancestors came to Japan during the Japanese rule of Korea (1910-1945). ${ }^{5}$ Even though modern zainichi Koreans appear indistinguishable from the Japanese due to high level of social and cultural assimilation, they are categorised as foreign residents unless they undergo a strict process of naturalisation. ${ }^{6}$

Table 1. Foreign population and international marriages in Japan

\begin{tabular}{|l|c|c|}
\hline & $\begin{array}{c}\text { Nationality of foreign spouse } \\
\text { (as \% of all foreign spouses) }\end{array}$ & $\begin{array}{c}\text { Nationality of foreign residents } \\
\text { (as \% of all foreigners) }\end{array}$ \\
\hline China & $30,9 \%$ & $32,0 \%$ \\
\hline South Korea & $18,3 \%$ & $22,0 \%$ \\
\hline Philippines & $15,4 \%$ & $10,3 \%$ \\
\hline USA & $6,3 \%$ & $2,3 \%$ \\
\hline Thailand & $4,6 \%$ & $2,0 \%$ \\
\hline Brazil & $3,0 \%$ & $7,8 \%$ \\
\hline
\end{tabular}

Source: Ministry of Health Labor and Welfare, Vital Statistics of Japan, 2016; Ministry of Justice, Statistics on the Foreigners Registered in Japan, Statistics on the Foreigners Registered in Japan, 2015.

There are, however, notable gender differences, as seen in fig. 2.

4 Ministry of Health Labor and Welfare, Vital Statistics of Japan, 2016.

5 Out of the 2 million Koreans who came to Japan under colonial rule (part of them forced to migrate as low-wage labourers), approximately 650,000 remained in Japan after 1945, forming the basis of today's zainichi Koreans. S.I. Lee, Diversity of Zainichi Koreans and Their Ties to Japan and Korea, Working Paper Series: Studies on Multicultural Societies, no. 8, Ryukoku University Afrasian Research Centre, 2012, p. 3, http://afrasia.ryukoku.ac.jp/publication/upfile/WP008.pdf (accessed: 15.05.2018).

6 Ibidem. 


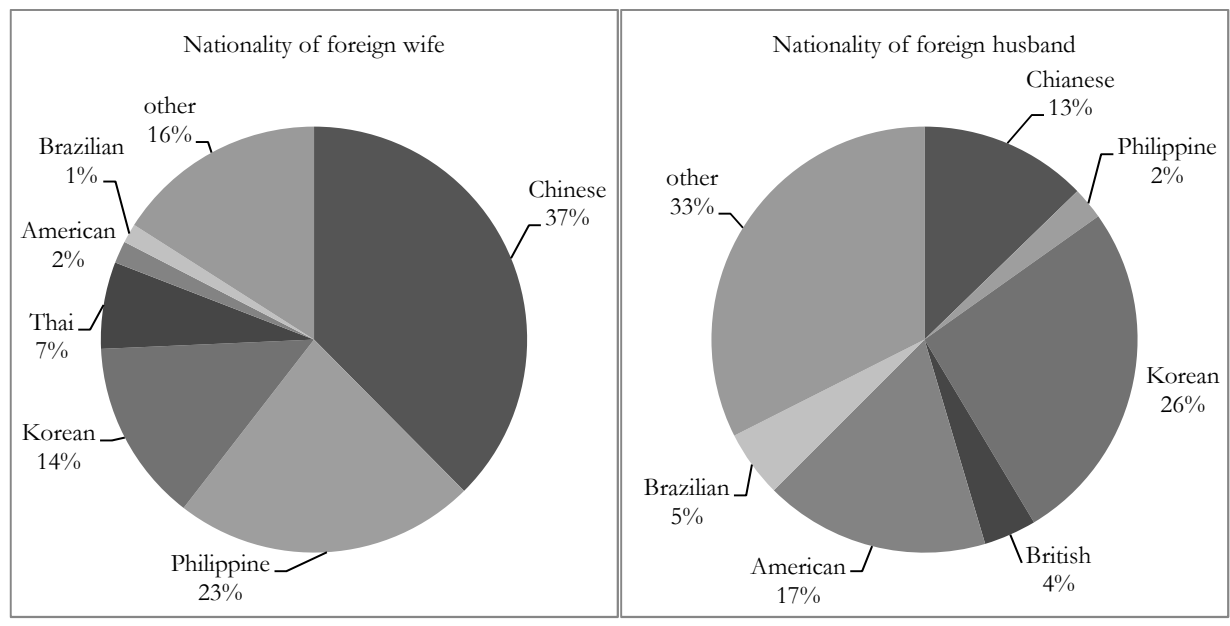

Fig. 2. Nationality of foreign wives (as \% of all foreign wives) and of foreign husbands (as \% of all foreign husbands)

Source: Own elaborarion based on Ministry of Health Labor and Welfare, Vital Statistics of Japan, 2016.

When a Japanese man marries a foreigner, the bride is most likely to be a national of other East or Southeast Asian countries. Chinese women are by far the most popular marriage partners (37\%), followed by Philippinas (23\%), Koreans $(14 \%)$ and Thais $(7 \%)$. Marriages between Japanese men and "Western" women are very rare. Americans - who are the most numerous in this category - constiute less than $2 \%$ of all foreign brides.

When a Japanese woman marries a foreigner, the pattern is less clear-cut. Koreans are the number one foreign spouses $(26 \%)$, followed by Americans (17\%), Chinese (13\%), Brazilians (5\%) and Brits (4\%). Japanese women are thus considerably less likely than their male counterparts to choose Asian spouses, except for Koreans, the majority of whom however are Japan-born and raised zainichi Koreans that appear culturally indistinguishable from the Japanese, as explained above. At the same time, Japanese women have a stronger tendency to marry Westerners, American and British hubsands being significantly over-represented among foreign sposuses compared to the number of US and UK residents in Japan. In addition, the share of spouses of "other nationalities" is twice higher in the case of foreign husbands (32\%) than in the case of foreign wives (16\%) and includes considerably more Westerners, such as Canadians, Australians and the French. ${ }^{7}$

This different gender pattern in the nationality of spouses has been explained in the literature by gender and power relations in the contemporary international order. In great simplification, low-status men who cannot find wives in their own country look

7 S. Takeshita, Intermarriage..., p. 177. 
for "ideal, traditional brides" in countries with lower (perceived) status. The women in turn see international marriage as an opportunity for economic or social mobility. ${ }^{8} \mathrm{Com}$ pared to other Asian countries, Japan - as a former coloniser and an economic power enjoys higher perceived status. Compared to the Western world, in particular the United States, it "ranks" lower as a non-White nation that was occupied during the post-war period. .' And thus, Asian brides have been particularly in demand in Japan's rural areas that suffer from shortage of marriageable women, as young Japanese females leave for the towns. A considerable proportion of these Asian (especially Chinese) brides are being "imported" to Japan via specialised matchmaking agencies. ${ }^{10}$ Other unions may start as "love marriages," especially in the case of Filipinas who arrive to Japan to work as "entertainers" in bars and nightclubs. ${ }^{11}$ At the same time, an increasing number of Japanese female "office workers" dream of marrying Western men, in the hope of finding romantic love and escaping the patriarchal gender expectations of their own culture. ${ }^{12}$

\section{Analysis of marriages between western women and Japanese men}

The focus of this paper is marriages of Western women and Japanese men. These "atypical" unions are by far the least popular and the least researched type of international marriage in Japan. They are particularly interesting in that do not follow the usual power-logic, whereby the groom should come from a country with higher (perceived) status. How do these marriages function? To what extent are spouses satisfied with various aspects of their marriage? What are the main sources of marital conflict and are they more linked to cultural differences or to individual traits of the spouses? What are the societal attitudes towards Japanese-Western marriages? These are some of the questions that this paper attempts to address.

8 S. Yamashita, Transnational migration of women: Changing boundaries of contemporary Japan [in:] Multiculturalism in the New Japan: Crossing the Boundaries Within, eds. N.H. Graburn, J. Ertl, R.K. Tierney, Berghahn, New York - Oxford 2008, pp. 109-110; G. Jones, International Marriage in Asia: What We Know, and What We Need to Know?, Asia Research Institute Working Paper Series, no. 174, National University of Singapore, Singapore 2012, pp. 6-11, http://www.ari.nus.edu.sg/wps/ wps12_174.pdf (accessed: 15.05.2018).

9 S. Yamashita, Transnational migration..., p. 110.

10 One study calculated that at least one-third of all international marriages registered in Japan are agency-based marriages. Y. Ishikawa, Role of Matchmaking Agencies for International Marriage in Contemporary Japan, “Geographical Review of Japan” 2010, Series B, vol. 83, issue 1, pp. 1-14.

11 L. Faier, Intimate encounters: Filipina Women and the Remaking of Rural Japan, University of California Press, Berkeley 2009.

12 K. Kelsky, Women on the Verge: Japanese Women, Western Dreams, Duke University Press, Durham 2001; S. Yamashita, Transnational migration..., pp. 105-107. 


\section{Literature review}

Cross-cultural research - notably by Hofstede and Triandis - has highlighted the collectivistic nature of Japanese society, as opposed to Western individualist cultures. The Japanese were found to value group (family, company) loyalty over individual goals and opinions, and to assign greater importance to hierarchy and social norms than representatives of Western cultures. ${ }^{13}$ Further research on the impact of the individualism-collectivism dimension at the level of personal relationships pointed to differences in communication styles and in the experience and expression of intimacy across countries. Members of more collectivist cultures like Japan are characterised as using more indirect and consensual communication strategies and putting less emphasis on (expressing) romantic love in intimate relationships. ${ }^{14}$

Research specifically on the functioning of Japanese-Western marriages is still scarce, in particular in the case of Western wife - Japanese husband marital combination. Skowronski et al. reviewed the various factors affecting marital satisfaction in Westerner and non-Westerner couples, including language and communication, attitudes towards marriage, societal attitudes, financial issues and child rearing. ${ }^{15}$ As for empirical research, Nakamura focused on transmitting different aspects of the spouses' cultures to mixed children in twelve families with Japanese mothers and British fathers residing in the UK. The study found that, while negotiation of cultures is indeed a significant characteristic of mixed families, these do not necessarily fall along national lines (e.g. a child may be encouraged to study Gaelic by a Japanese mother and to practise kendo by a Scottish father). Mixed families appeared to hold on to the Japanese familial model of soto/uchi (inside/outside), with husbands working outside of the home (soto) and stay-at-home wives $(u c h i)$. While fathers participated in parenting, their responsibilities tended to surround the public sphere (e.g. school or doctors) the mothers remaining primarily responsible for the domestic sphere (e.g. feeding the family and housekeeping duties). ${ }^{16}$ Yamamoto - based on her interviews with nine Western-Japanese couples residing in Japan - found evidence of soto/uchi divide among couples bringing together Western wife and Japanese husband but not among

13 E.g. G. Hofstede, Culture's consequences, Sage, Beverly Hills, CA 1980; H.C. Triandis, Culture and social behavior, McGraw-Hill, New York 1994.

14 E.g. W.B. Gudykunst, T. Nishida, Bridging Japanese / North American differences, Sage, Thousand Oaks, CA 1994; K.K. Dion, K.L. Dion, Individualistic and collectivistic perspectives on gender and the cultural context of love and intimacy, "Journal of Social Issues" 1993, vol. 49, issue 3, pp. 53-69; iidem, Individualism, collectivism, and the psychology of love [in:] The new psychology of love, eds. R.J. Sternberg, K. Weis, Yale University Press, New Haven, CT 2006, pp. 298-312.

15 D. Skowroński, A.B. Othman., D. Tan Wen Siang, G. Lum Wei Han, J. Wong Jia Yang, K. Waszyńska, The Outline of Selected Marital Satisfaction Factors in the Intercultural Couples based on the Westerner and non-Westerner Relationships, "Polish Psychological Bulletin" 2014, vol. 45(3).

${ }_{16}$ M. Nakamura, Mixed Families: An Ethnographic Study of Japanese/British Families in Edinburgh. $\mathrm{PhD}$ thesis, University of Edinburgh, 2014, https://www.mobt3ath.com/uplode/book/book11387.pdf (accessed: 15.05.2018). 
those with Japanese wife and Western husband. She also found that among the latter couples, there was more equitable division of household labour and less conflict over child-rearing issues, suggesting that it is the nationality of wife that has a major impact on the reproductive domain. Finally, Japanese men and women entering crosscultural marriages were already "internationally minded" before they met their future spouses. ${ }^{17}$ Skowronski, Andrews and Kobayashi investigated the sexual and marital satisfaction in Western-Japanese couples. Curiosity towards a new culture was one of the most significant factors when forming the relationship. The overall couple satisfaction averaged 4.0 out and sexual satisfaction -3.8 out of 5 . Miscommunication and differences in the definitions of intimacy were by far the primary causes of conflict. ${ }^{18}$

\section{Methods}

The A questionnaire was created in order to ascertain the level of marital satisfaction, main factors influencing marital well-being and societal attitudes towards couples of Western women and Japanese men. The draft questionnaire was consulted with two experts in the field. In addition to demographic questions (including age, sex, nationality, education, occupational status, financial situation, place of residence, length of marriage, and languages spoken at home), the final questionnaire contained eight questions covering (1) satisfaction with various aspects of marriage; (2) frequency of disagreements or arguments; (3) main sources of marital conflicts and (4) whether they are more often linked to cultural or psychological differences between spouses; (5) challenges and (6) positive sides of being in a cross-cultural marriage; (7) prejudice towards mixed marriages in Japan and in home country; and (8) desired change to different aspects of marriage. Two of these were open-ended questions and six were closed-ended, Likert-scale questions with a possibility to add comments.

An email invitation to participate in the survey was sent to the coordinators of two English-speaking networks of female expats living in Japan - Association of Foreign Wives of the Japanese and K-A International Mothers in Japan - who distributed it to their members. Respondents were directed to a website containing the questionnaire. A total of 41 valid responses have been collected in June 2017. Because of the relatively small sample, results are reported as absolute numbers rather than percentages in graphs. Where available, quantitative findings are illustrated by qualitative comments. The survey has been limited to foreign wives of the Japanese, as there appear to be no equivalent groups of Japanese husbands.

17 B.A. Yamamoto, International Marriage in Japan: An Exploration of Intimacy, Family and Parenthood, 18th Biennial Conference of Asian Studies. Association of Australia. Adelaide, 5-8 July 2010, https://www.researchgate.net/publication/282121752_International_Marriage_in_Japan_ An_Exploration_of_Intimacy_Family_and_Parenthood (accessed: 15.05.2018).

${ }_{18}$ D. Skowronski, J. Andrews, M. Kobayashi, The Sexual and Marital Satisfaction in Intercultural Western-Japanese Committed Romantic Relationships. The Implications for Sex Therapy and Couple Counselling Based on the Qualiltative Study, "The Journal of Sexual Medicine” 2015, vol. 12, p. 336. 
All forty-one respondents are "Western" women currently married to Japanese men. Thirty-eight are native English-speakers from Anglophone countries: United States (20), United Kingdom (9), Australia (6) and Canada (3). All respondents have an experience of living in Japan of at least 3 years and an average of 17.5 years. Thirty-nine resided in Japan at the time of the survey. ${ }^{19}$ The average age of the respondents and their husbands is, respectively, 40.5 and 45.5 years, and the average marital experience is 13 years. The vast majority of both spouses have at least a college or university diploma. The majority of couples are dual-earner couples, even though the wives are more likely to work part-time or to be self-employed. Most couples have at least one child and live in cities of over 100,000 inhabitants. As shown in fig. 3, almost two out of three respondents describe their financial situation as "very easy" or "fairly easy."

Seven out of ten respondents say they speak Japanese "fluently" or "fairly well" and the same number say the same about their husband's knowledge of English (fig. 4). In all couples, at least one partner speaks fluently or fairly well the other partner's language and in 4 out of 10 couples this is the case for both spouses. Half of the respondents speak English with their spouse and a quarter each speak Japanese or both languages.

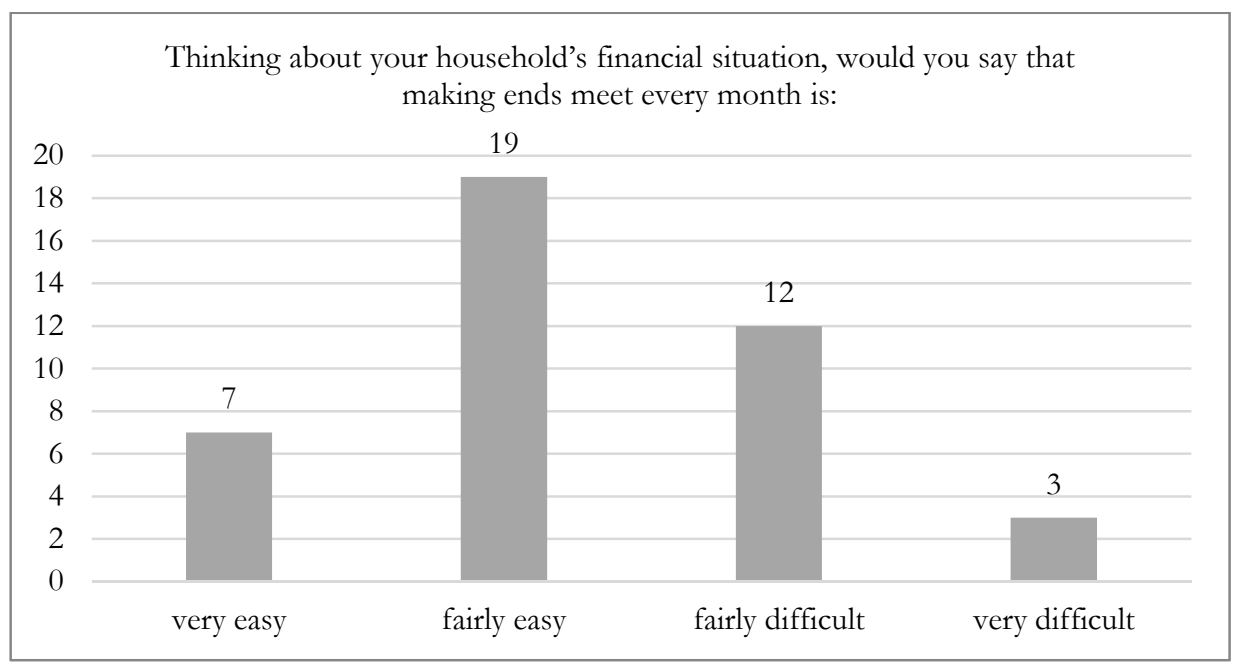

Fig. 3. Self-declared financial situation

Source: Own elaboration based on survey results.

19 One lived in Singapore and one lived temporarily (until the completion of her studies) in the UK while the husband lived in Japan. 


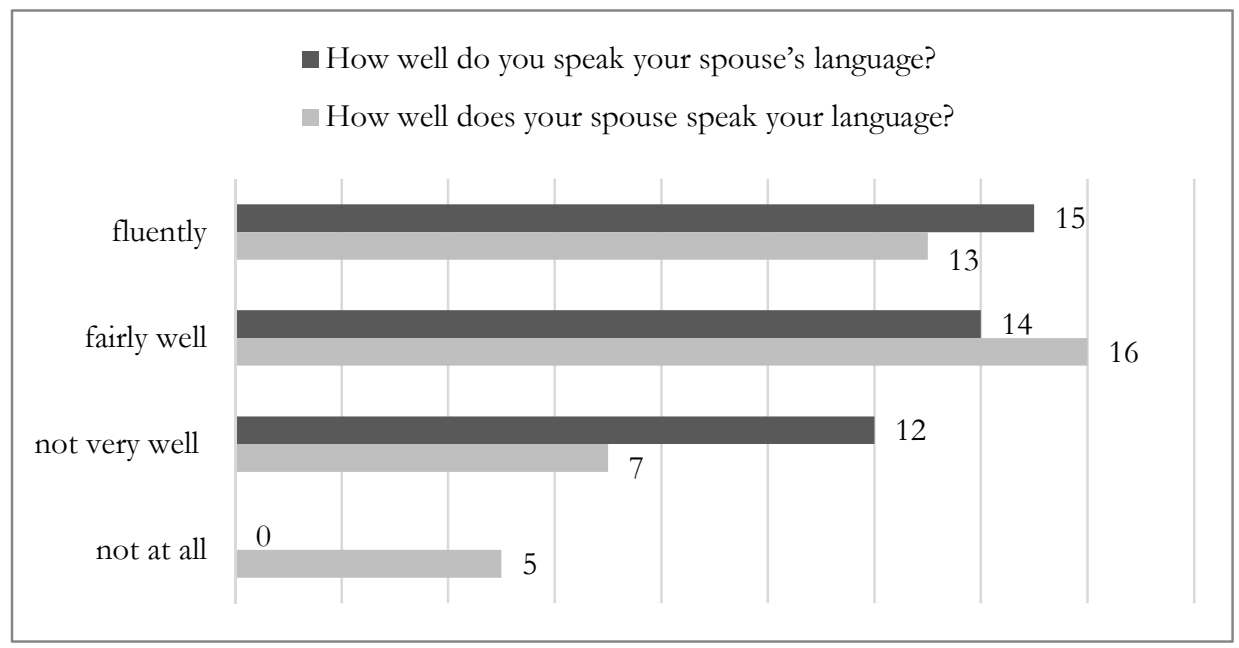

Fig. 4. Knowledge of each others' languages

Source: Own elaboration based on survey results.

Satisfaction with various aspects of marriage

As indicated in fig. 5, over three in four women who took the survey (32) say that they are "very satisfied" or "fairly satisfied" with their marriage in general as well as with the emotional connection with their spouse (31). The level of satisfaction is even higher when it comes to intellectual connection with their partner (35). Sexual relations appear to be the least satisfactory aspect of marriage, over half of foreign wives saying they are "not very satisfied" or "not at all satisfied" with sex life in their marriage (23). "My spouse and I have a very satisfactory marriage in all ways except sexually. Our sexual needs are on opposite ends of the spectrum and it has been a source of conflict, hurt, anger, and deep frustration throughout our marriage," says one respondent. With the workplace culture in Japan, the overwork hours and mental demand remove all energy and time necessary for an active sexual connection," adds another one. Both respondents - while "not at all satisfied" with sex life in their marriage - still describe themselves as "fairly satisfied" and "very satisfied," respectively, with the marriage overall. This may point to a certain degree of rationalisation, with other aspects of marriage seen as compensating for inadequate sex life.

Contrary to expectations, the financial situation and the level of proficiency in each other's language do not appear to have a big impact on the well-being of the marriage. The reported levels of marital satisfaction are not considerably higher when the couple enjoys easy or very easy financial situation and when both spouses speak fluently or fairly well each other's language and are actually somewhat lower when the spouses communicate in English. 


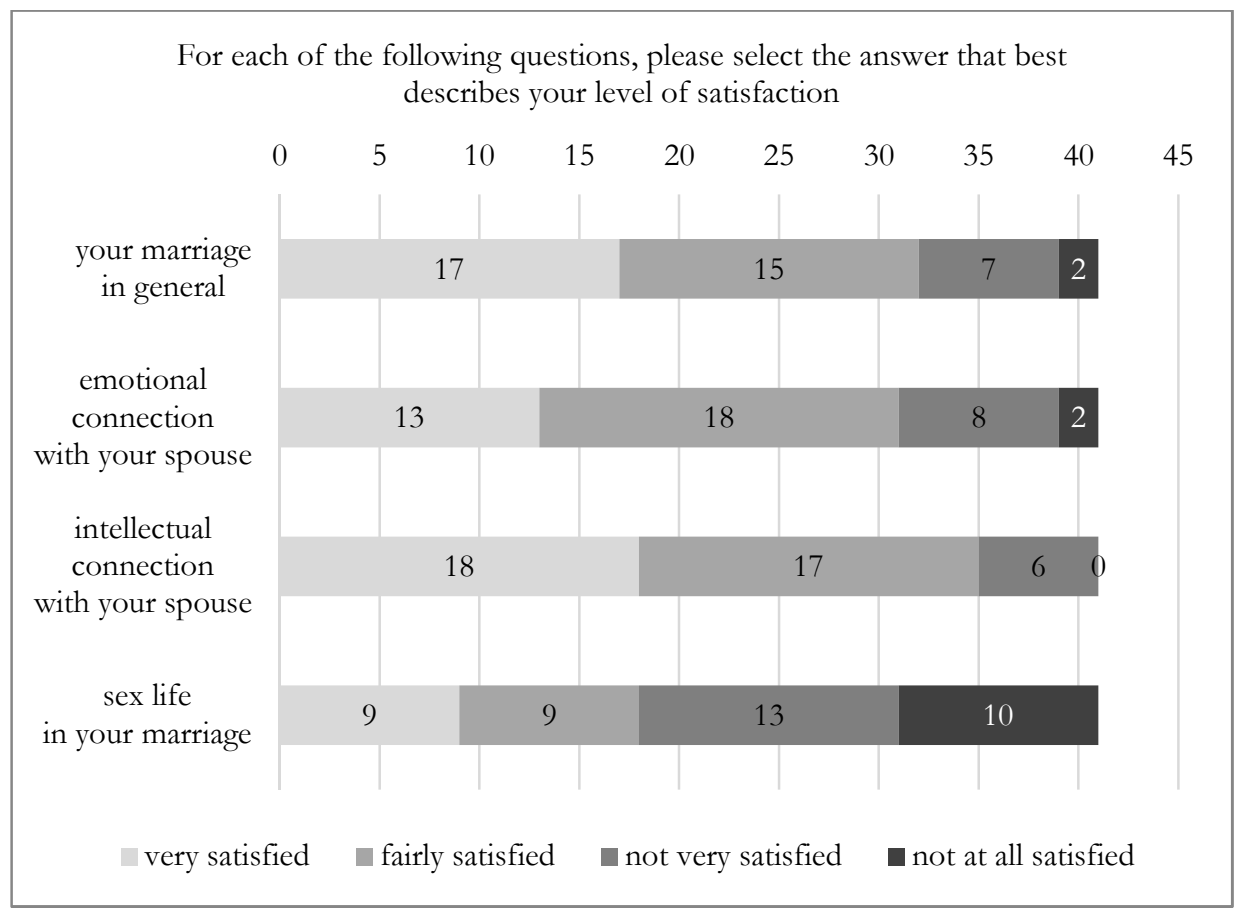

Fig. 5. Satisfaction with various aspects of marriage

Source: Own elaboration based on survey results.

\section{Main sources of marital conflicts}

Figure 6 shows the replies to the question about the relative importance of different factors as sources of marital conflicts.

While language issues as such do not appear to be a major problem, differences in communication styles are seen as a "very important" or "fairly important" cause of marital conflicts by two-thirds (27) of respondents. A number of them express frustration at their husbands' lack of openness and fear of confrontation. Here are some of the voices: "When upset, I tend to raise my voice. He will go silent and does not respond. Nothing comes from such an exchange," "[He is] uninterested in partners' conversation, hence the conversation doesn't lead anywhere," "My standing up for my ideas, or disagreeing with his, gets translated into arrogance," "He has a sort of defeatist attitude about many things and my American background tends to make me think I can fight my way through anything and accomplish my goals."

Just over a half of respondents (21) see different visions of marriage as a "very important" or "fairly important" cause of marital conflict. However, they do not elaborate further on the issue, except perhaps for this one comment: "My husband 


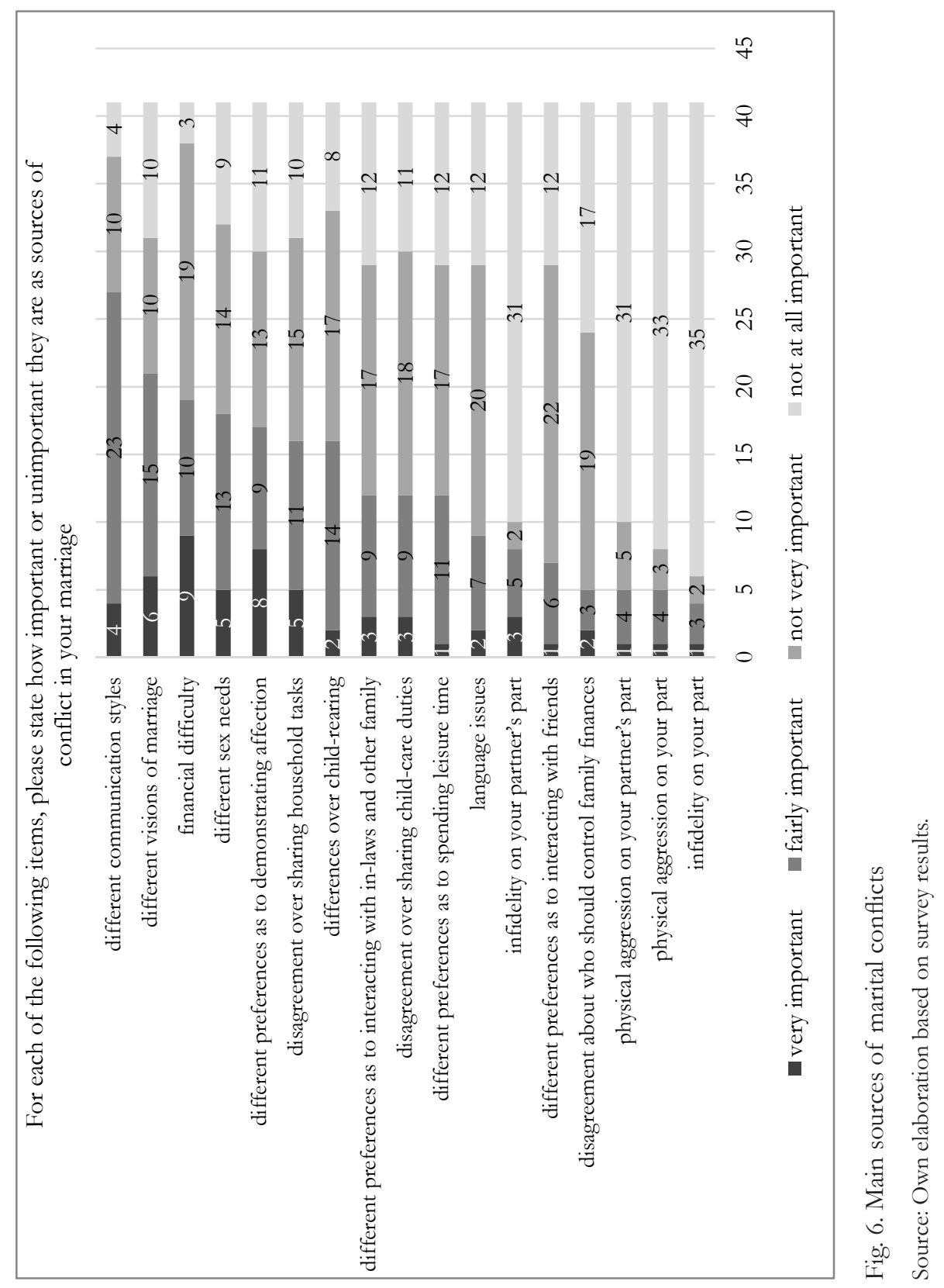


and I disagree on what it means to be in love. It's a much much deeper and stronger thing for me than for him. It's fleeting and fluctuates for him, this is what I consider liking or not liking someone. Love doesn't just go away for me, for him it does."

Even though the majority of respondents describe their financial situation as very or fairly easy, nearly half (19) mention financial difficulty as well as their husbands' incompetence with money as an important source of conflict. On the other hand, very few respondents (5) mention disagreements over who should control family finances, which could suggest that the husbands leave this task to their wives, in line with the Japanese tradition. "Money is the only thing we argue about. He is terrible with money and knows it, so he's happy for me to control the family finances but still manages to get into debt," says one respondent. "My husband is extremely irresponsible with money. This is the greatest source of conflict in our marriage," adds another one.

Different sex needs and different preferences as to demonstrating affection rank as fourth and fifth important causes of marital conflicts (mentioned, respectively, by 18 and 17 respondents). Qualitative comments again indicate an attempt at rationalisation on the part of the foreign wives. A respondent in her mid-forties notes: "Sex does not play a big part of marriage in Japan, I think. I had 'my fill' in my youth." Another one with a 26-year marriage experience says: "At the start of our marriage, his lack of outward or public affection bothered me (...) But eventually after a lot of going round with arguments and fights, I understood that he does love me very much and I don't need him to demonstrate that publicly any more (...)."

Disagreement over sharing household tasks and differences over child-rearing are mentioned as "very important" or "fairly important" by 4 out of 10 foreign wives (16 each). While none of the respondents elaborates on the issue of child-rearing, a number of them express disappointment at their husbands' traditional gender roles expectations and the unequal division of household chores. While some contribute substantially to household income or are even primary breadwinners, they still tend to take on most housework. An Australian respondent notes: "Financially, we both must work hard in order to afford our lifestyle. (...) Living in Japan, my husband has conflicted expectations of a wife's role. In my home country, females are equal to their spouses, and work is expected while the male cares for the children at home." Her compatriot adds: "[My husband's] work situation is prioritized ahead of our family needs. If [he] is sick, I have to stay home (...) He earns less than me but his job is more important (...) I am doing the most housework, am in charge of child rearing and funding our life but I have less rights in our marriage."

Among the less common sources of marital conflicts, 8 respondents mention infidelity on their partners' part and 4 - their own infidelity as an "important" or "fairly important" factor. Four each say the same about physical aggression by their husbands or their own physical aggression.

Finally - while not mentioned among the reply options - a couple of respondents evoke different visions of work-life balance. "[For my husband] work is of 
foremost importance, and leisure is afforded only at certain points of the year (live to work), whereas I enjoy leisure time and work towards free-time goals (work to live)," says one respondent.

\section{Desired change in different aspects of marriage}

Respondents were asked whether, if they could change something in their marriage, they would like to see "more, less or the same level" of different things. The results are shown in fig. 7. Two out of three foreign wives (27) say they would like to see more lovemaking. "While I feel my spouse shows affection to me in various forms, we almost never have sex. Basically sex is for reproduction only, as it is too 'troublesome' otherwise (...)," says one woman. "I find attitudes to relationships and sex in Japan to be totally exclusive. It seems love and sex are only for attractive young people, those who are not young and attractive must pay, settle, or do without -it's madness," remarks another one.

The majority of respondents (25) would also like to see more leisure time together, such as travel, hobbies, going out. "This is a matter of us both being too busy to have much time left for leisure or going out," says one respondent.

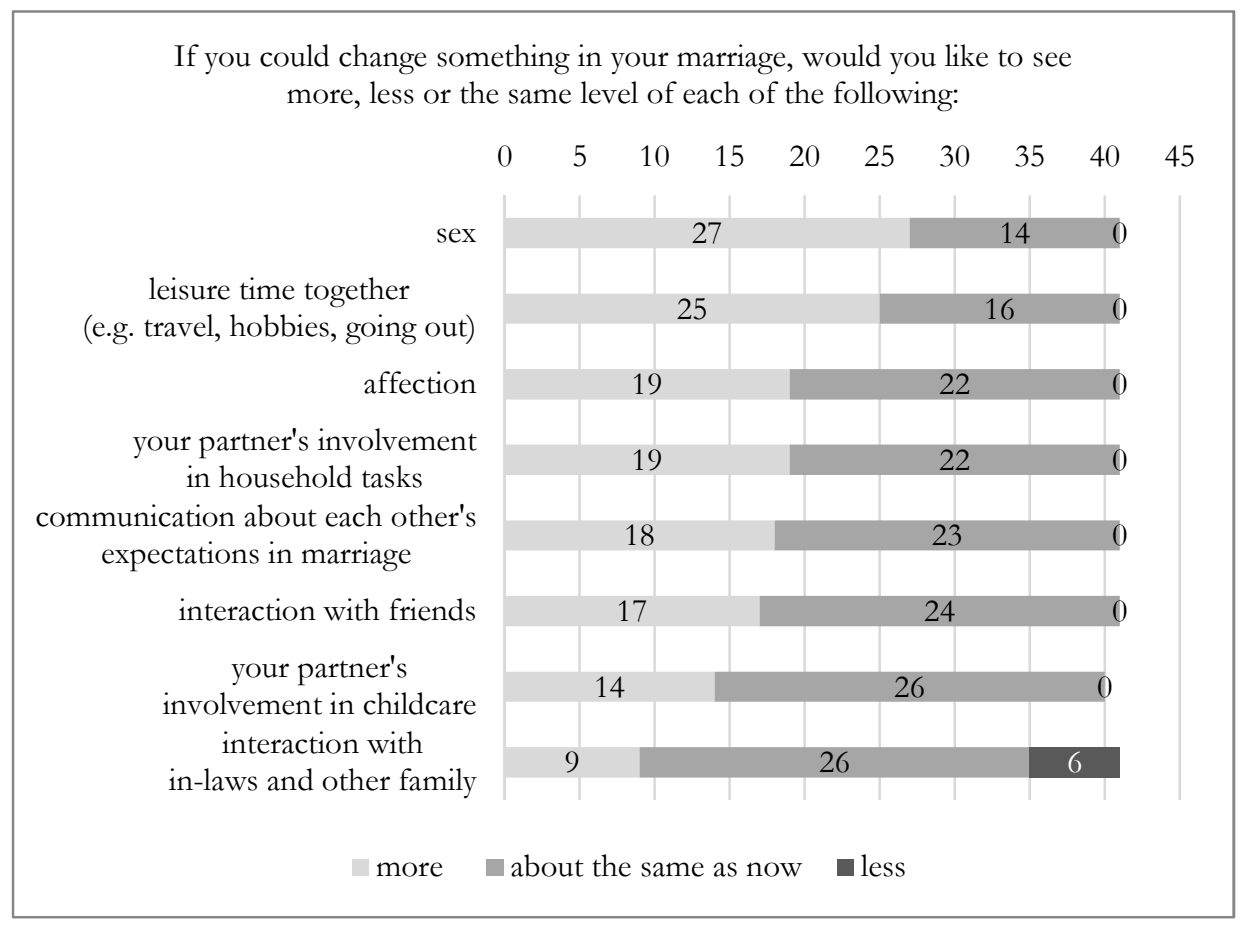

Fig. 7. Desired changes in different aspects of marriage

Source: Own elaboration based on survey results. 
Around 4 in 10 respondents would like to see more affection (19), more partner's involvement in household tasks (19), more communication about each other's expectations (18) and more interaction with friends (17).

Regarding the division of household tasks, one American respondent notes: "he tends to think he's so much more helpful than J[apanese] husband... which he may be, but compared to a lot of friends back home, he's just average. So I think he thinks he's awesome and I think he's just doing what's normal." Another one complains: "All household tasks fall to me because my husband views it as a waste of time."

As for communication, one respondent says: "We rarely talk about our marriage except when we fight. I would really like to set some ground rules about that." Another one notes: "Communication just seems difficult in general. We've gone to counselling, but we probably need to go again and do some follow up. When we lack sleep and energy... it's hard to give much more or give a shit about the other person."

Regarding interaction with friends, respondents say: "I've found it hard for us to even have couple friends that we both enjoy", "Family comes before friends. Would like to see his fun side more" and "I'd like him to go out with his friends more. I go out often with mine, or I take trips to meet friends, he never does. He might go out once a year with friends, that's about it."

The fewest respondents (9) wish for more interaction with in-laws and other family whereas some (6) would actually rather have less of it. "My husband is very different from his family so they aren't people I would choose to hang out with if they weren't family. Where his family is involved is usually where conflict comes in our marriage," says one respondent.

\section{Psychological vs. cultural sources of marital conflicts}

Respondents were asked whether in general their marital conflicts were more often linked to psychological differences between spouses, more often linked to cultural differences or equally often linked to both. The vast majority of foreign wives judge that disagreements are linked primarily to psychological differences (18) or equally often linked to psychological and cultural differences between spouses (17). Only 5 respondents give primacy to different cultural backgrounds over personality traits (fig. 8). "My husband has had a lot of western influence and I have lived a long time in Japan so I don't feel cultural differences are as weighty on our conflicts as psychological differences are," says one respondent. At the same time, some comments indicate that personality may be culturally influenced too: "I think [our conflicts] stem from the fact that he is the eldest son and that is a cultural difference but it has had an enormous effect on his psyche turning into a psychological aspect as well," "Most of our fights have been due to issues with communication that are more personal than cultural - unless one attributes openly talking about their feelings and worries as a cultural thing for foreigners and the exact opposite of it to Japanese men." 
Thinking in general about conflicts in your marriage, would you say they are:

more often linked to psychological differences between spouses

more often linked to cultural differences between spouses

equally often linked to both

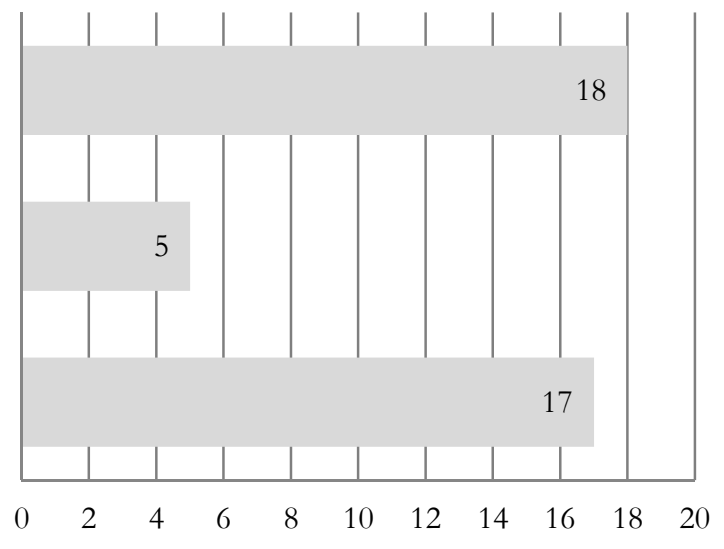

Fig. 8. Psychological vs. cultural sources of marital conflicts

Source: Own elaboration based on survey results.

\section{Challenges due to cultural differences}

Replies to an open-ended question about the challenges faced in their marriage because of cultural differences between spouses show a range of experiences. While some women see the fact of being in a cross-cultural marriage as an important challenge ("Different [cultural] expectations for almost everything (...) put a thick layer of icing on top (icing not in a good way)"), for others it is a non-issue ("I don't see my husband as a foreigner. He is just a person to me, whom I love deeply" or "I didn't marry a nationality, I married a man").

Among the key challenges of being married to a Japanese man, respondents evoke once again different communication styles ("My standing up for my ideas, or disagreeing with his, gets translated into arrogance") and different ways of showing affection ("The lack of physical expressions of affection as well as the lack of verbal declarations make it hard to know if he cares").

A number of foreign wives complain about the primacy of work over family ("He thinks nothing of working long hours for low pay, as long as he has a steady job. I think as a foreigner I would not hesitate to protest such conditions to my boss, especially if they were affecting my relationship with my family," "Our marriage goes through good and bad patches, directly connected to how well or bad my husband is doing at work").

There is also some resentment towards husbands' lack of engagement in household chores and child-rearing ("He thinks he is a super hero, I think he should do 
more, "My husband acts like a paying guest in the family home and asks me not to consider him because he doesn't want to be bothered to consider me").

Finally, "other people's expectations of how our family should or shouldn't be" and interactions with in-laws who are "not as forgiving [as my husband] when I don't fit their cultural standards" may be troublesome.

Advantages of being in a cross-cultural marriage

As for the "positive sides of being married to a foreigner," having a Japanese husband means that "life is interesting" and there is "never a dull moment."

Many women value the cultural and linguistic diversity that comes from having roots in two cultures at once. "Learning about a different way of living and thinking, as well as learning a different language, often provides unique insights," remarks one respondent. "Having children together has meant having two cultures full of celebrations and it's been fun to learn not only the Japanese customs for kids but in teaching them to foreigners, I've learned so much about my own culture, too," says another.

There is also a general agreement that the very anticipation of a "culture clash" diminishes its importance. "When there are disagreements, I think we tend to be more lenient with each other due to our past understanding that sometimes it's simply a cultural or linguistic misunderstanding," "We never took cultural differences as a huge sign of trouble, they were expected blips on the road. Two Americans or Brits or Japanese could get married and have immense cultural differences that they might not have expected. The fact that we were expecting them immediately reduced them in size and worry factor," "Differences can be settled as "agree to disagree" more often," "We knew we would have to communicate a lot going in so we probably have a higher base level of communication than couples that are from the same culture (but probably have very different world views anyway"), claim the respondents.

Prejudice towards mixed marriages in Japan and in home country

Figure 9 demonstrates replies to the question about prejudice towards mixed marriages in Japan and in their home countries.

Overall, slightly over half of foreign wives "strongly agree" (3) or "tend to agree" (19) that there is prejudice towards mixed marriages in Japan, even though a number of them say that they have heard about it from others rather than experienced it themselves. It is primarily the "unusual" combination of a Japanese man and a western woman that arouses surprise and questions, even though "not necessarily in a bad way." Here are some of the voices: "Japan is still very traditional. 
My husband is famous at work because he's the only person married to a white foreigner," "Marriages of white women with Japanese men in Japan are considered unusual to the point where my husband is sometimes thought of as Chinese and complemented on his Japanese ability by fellow Japanese (typically older men). While funny, the assumption is that there is no way a white girl would marry a Japanese guy." Some respondents also recall the initial reluctance of their parents-in-law, social ostracism ("we're not included in a lot of group gatherings. When we are included, no one tries to talk to me (...) I feel very on-the-outside when I'm around Japanese couples") and the discrimination faced by their kids ("People said our kids would be disabled because of the mixed blood," "Our kids are bullied for being hafu [half-foreigners]").

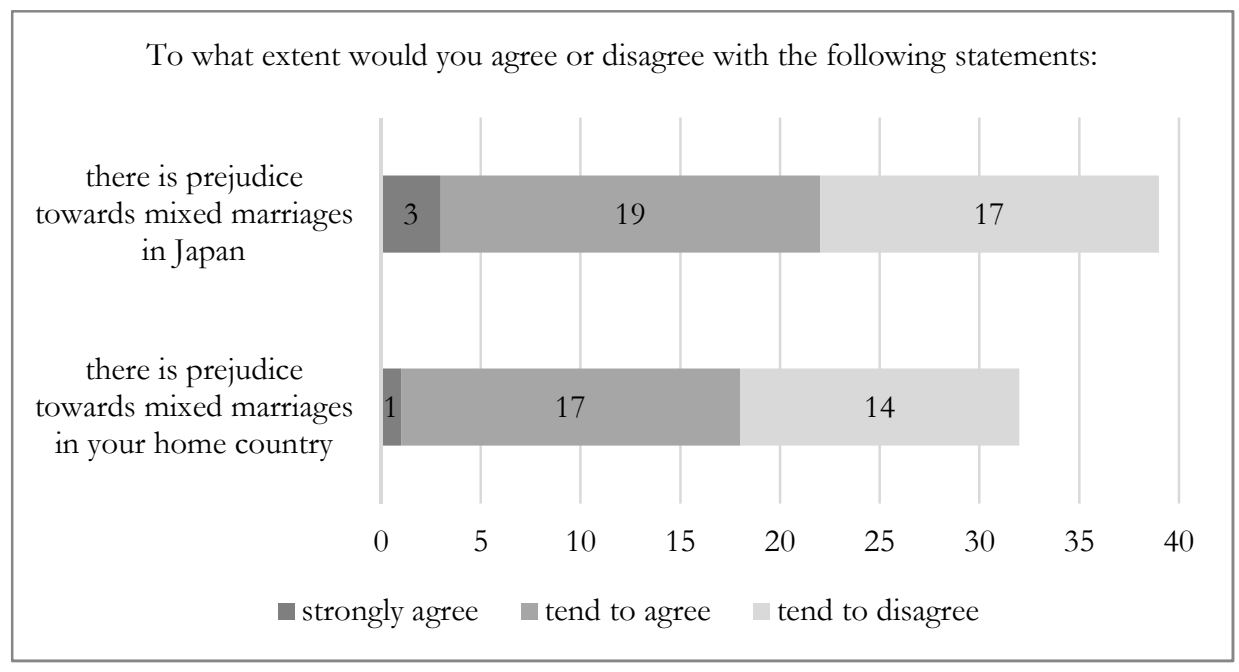

Fig. 9. Perceived prejudice towards mixed marriages in Japan and in home country Source: Own elaboration based on survey results.

Just over 4 out of 10 respondents, primarily those from the US, "strongly agree" (1) or "tend to agree" (17) that there is prejudice towards mixed marriages in their home country, especially when the husband is Asian. "In America, (...) I have felt strong resistance to interracial marriage my entire life. Growing up, I was told 'A bird and a fish can fall in love, but where will they make their home?' And 'like should stick to like'," says one American respondent. Her compatriot adds: "Americans think it is odd that I married a Japanese man." "If you are white then it's cool and trendy here, [in Japan], but there have been a couple of barbed comments in my home country for me marrying someone who isn't white. I think this would differ with the couple's racial combination," notes a British respondent. This is echoed by 
a respondent from Eastern European country: "In my home country, there is a very strong prejudice against 'our' women marrying 'dirty foreigners' and not 'us.' The prejudice gets even worse when the marriage is interracial, and women are considered 'traitors' and other sexually-based slurs. When we decided to marry, some of the friends from my home country told me they were surprised since they thought it was just a fling (...) and they didn't think I'd marry an 'Asian guy'."

Perhaps not surprisingly, given that the vast majority of respondents currently reside in Japan, those who agree that there is prejudice towards mixed marriages in Japan also report lower overall levels of satisfaction with their marriage. This is not the case for those who see such prejudice in their home country.

\section{Conclusions}

Marriages of Western women and Japanese men are a particularly interesting type of international marriage because they do not follow the usual power-logic, whereby the groom comes from a country with higher (perceived) status.

The results of an online survey with Western women married to Japanese men show that overall around 8 out of 10 respondents are satisfied with their marriage in general as well as with the intellectual and emotional connection with their spouse. Sex life appears to be less satisfactory, over half of foreign wives saying that they are not satisfied with this aspect of marriage and two in three wishing for more intimacy. At the same time, the cultural context (i.e. the fact that sex constitutes a less important component of marriage in Japan than in the West) seems to serve as a rationalisation for some of the respondents. The findings appear consistent with those of Skowronski et al. where satisfaction with sex life was also lower than overall marital satisfaction.

Again in line with Skowronski et al., differences in communication styles and in the display of affection are seen as important causes of marital conflicts. Four in ten respondents would like to see more open communication with their spouses and more expression of feelings. The qualitative comments point to a certain tension between more indirect communication style and conflict avoidance typical for collectivistic high-context cultures and more direct, confrontational style characteristic for individualistic, low-context cultures, as well documented in the literature.

As for the functioning of mixed households, there is little evidence of a sotouchi divide found in couples bringing together Japanese wives and Western husbands, since the majority of foreign wives contribue to household income. At the same time, while Yamamoto found Japanese husbands "ready or resigned to taking a role in household chores," in the present study a considerable proportion

of foreign wives expressed disappointment at the unequal division of housework 
and the priority of husbands' work over family life. Disagreements over managing family finances, child-rearing and interacting with in-laws appear to be less of an issue. While nearly half of respondents mention financial difficulty as an important source of marital conflict, very few evoke disagreements over who should control family finances. As for differences over child-rearing, 4 out of 10 respondents mention them as an important source of marital conflict but none actually elaborates on the issue. While some foreign wives do express irritation at their in-laws, others would actually like to see more interaction and help from their parents-in-law. This could perhaps, at least partly, be explained by Yamamoto's proposition that - in line with Japanese gender dynamic - "the woman will decide rules for the home and child raising, whether she is Japanese or not."

On the whole, there seems to be little evidence of a "culture clash" between foreign wives and Japanese husbands. While respondents evoke specific challenges due to cultural differences (such as different communication styles, sexual needs or gender-role expectations), overall a clear majority judge that the conflicts are more often linked to personality traits than to different cultural backgrounds of the spouses. As for the advantages of being in a cross-cultural marriage, many women value the diversity that comes from having roots in two cultures at once. Finally, there is a widespread agreement that the very anticipation of cultural differences diminishes their importance. It would therefore appear that culture differences are at the same time (seen as) an obstacle and as an asset in international marriages.

When interpreting the survey results, it should be borne in mind that the sample only included women who were in a relationship at the time of the survey. This is particularly important given that international marriages are statistically more likely to end up in divorce than mono-cultural Japanese couples.

The major limitation of this study lies in its limited sample size and the selfselection bias inherent in online surveys. It cannot be excluded that the respondents to the survey were either particularly satisfied or dissatisfied with their marriage, or otherwise different (e.g. more Internet-savvy, better-educated) than the general population of Western wives of the Japanese. Caution is therefore needed while interpreting the results. At the same time, it should be considered that online surveys have the advantage of providing access to small, hard-to-reach populations, such as the one in question. They also offer greater anonymity and confidentiality than faceto-face research and are thus particularly suitable to investigate "sensitive" issues such as sexual satisfaction. Like most research in this area, the survey was limited to the wives' perspective, as no groups of Japanese husbands married to foreign women have been identified. Finally, only selected variables that could affect marital satisfaction in international couples have been analysed. Despite the limitations, the paper may be useful in informing further research into marital satisfaction in intercultural couples. 


\section{STRESZCZENIE}

\section{MIĘDZYNARODOWE MAEŻEŃSTWA W JAPONII: SATYSFAKCJA MAŁŻEŃSKA PAR ZACHODNICH KOBIET I JAPOŃCZYKÓW}

Małżeństwa zachodnich kobiet z Japończykami sa zdecydowanie najmniej popularnym i najmniej zbadanym rodzajem małżeństw międzynarodowych w Japonii. Są one nietypowe w tym sensie, że nie podążają za zwykłą logiką władzy, podczas gdy pan młody pochodzi z kraju o wyższym (postrzeganym) statusie. Celem artykułu było zbadanie poziomu satysfakcji małżeńskiej, głównych czynników wpływających na dobre samopoczucie małżonków i postaw społecznych wobec takich związków. W badaniu wykorzystano ankietę przeprowadzoną wśród 41 zachodnich kobiet, które poślubiły Japończyków. Zdecydowana większość zagranicznych żon była zadowolona z różnych aspektów małżeństwa, z wyjątkiem życia seksualnego. Różnice w stylach komunikacji i wyrażaniu uczuć uznano za ważne przyczyny konfliktów małżeńskich. Jeśli chodzi o funkcjonowanie mieszanych gospodarstw domowych, to znaczna część cudzoziemskich żon wyraziła rozczarowanie z powodu nierównego podziału pracy gospodarstw domowych. Jednocześnie nieporozumienia dotyczące zarzadzania finansami rodziny oraz wychowywania dzieci czy interakcje z teściami wydawały się mniej problematyczne. Respondenci, którzy czuli, że istnieją uprzedzenia wobec małżeństw międzynarodowych w Japonii, byli mniej zadowoleni z ich małżeństwa. Ogólnie rzecz biorąc, niewiele jest dowodów na tzw. zderzenie kultur w małżeństwach zachodnio-japońskich. Podczas gdy respondenci przywoływali różnice kulturowe w konkretnych kwestiach (takich jak komunikacja, kwestie seksualne lub oczekiwania dotyczące roli płci), zdecydowana większość uznała, że konflikty są częściej związane z cechami osobowości niż z odmiennym pochodzeniem kulturowym małżonków. Jeśli chodzi o zalety bycia w małżeństwie międzykulturowym, to wiele kobiet doceniło różnorodność wynikająca z zakorzenienia się w dwóch kulturach jednocześnie. Panowała powszechna zgoda, że sama świadomość możliwości wystąpienia różnic kulturowych zmniejszyła ich znaczenie. 